$14^{\text {th }}$ Conf. Agric. Develop. Res., Fac. of Agric., Ain Shams Univ.,

March, 2019, Cairo, Egypt

Special Issue, 27(1), 749 - 760, 2019

Website: http://strategy-plan.asu.edu.eg/AUJASCI/

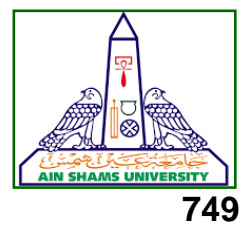

\title{
BIOLOGICAL CONTROL OF SOIL -BORNE FUNGAL PATHOGENS
}

Afifi M.A. ${ }^{1}$, Metry E.A. ${ }^{2}$, Ismail I.M. ${ }^{2}$ and Madkour M.A. ${ }^{1}$

1. Horticulture Dept., Fac. of Agric., Ain Shams Univ., P.O. Box 68 Hadyek Shoubra11241, Cairo, Egypt

2. Agriculture Genetic Engineering Research Inst., Agric. Res. Center, Giza, Egypt

*Corresponding author: madkour.magdy@gmail.com

Received 26 November, 2018,

Accepted 18 December, 2018

\section{ABSTRACT}

Seventeen bacterial isolates have been successfully isolated and purified from soil rhizosphere samples collected from different agricultural areas Buhayra, Sharqia and Alqilyubia of Egypt, and screened for production of chitinase enzymes had the highest chitinolytic activities amongst those investigated. Isolate S3-C and S1-C were Identified by biochemical, physiological tests and $16 \mathrm{~s}$ rRNA gene primer as Bacillus cereus S3C, Gene Bank NCBI accession MK185696 and Bacillus cereus S1C accession MK185697. The production of chitinase by B.cereus S3C and Bacillus cereus $S 1 C$ was optimized using colloidal chitin medium amended with $1 \%$ colloidal chitin at $30^{\circ} \mathrm{C}$ after five days of incubation. B.cereus S3C had potential for cell wall lysis of many phytopathogenic fungi tested such as Fusarium oxysporum and Rhizoctonia solani Potato phytopathogenic fungi by in vitro antagonistic test. The addition of $B$. cereus S3C chitinase was more effective than that of B.cereus $S 1 C$ in increasing the resistance of Potato plants infected with various Soil- borne phytopathogenic fungi.

Keywords: Biological control, Soil borne, Fungal pathogens, Bacillus cereus, Chitinase, Characterization, Optimization, Antifungal activity.

\section{INTRODUCTION}

Chitin is an insoluble polysaccharide composed of linear chains of $\beta-1,4-N$ acetyl glucosamine (GlcNAc) residues that are highly cross-linked by hydrogen bonds. Chitin is one of the most plenty biopolymers on earth, next to cellulose. Chitin is widely distributed in nature as it is found in the outer skeleton of insects, fungi, algae, crabs, shrimp, lobsters and in the internal structures of other invertebrates (Bhattachrya et al 2007).

We are facing in Egypt major issues when it comes to crop production due to the fungal diseases that infect the crops. Various kinds of fungal pathogens affect the soil in the crops yield. Major damage happens to the crops yield affect by the fungal species of Alternaria, Aspergillus, Fusarium, Macrophomina and Sclerotium in. For instance we find that severe damages occur to the rice crops where the soil infected by fungus as Rhizoctonia Solani and Pyricularia Oryzae which live endlessly in the soil as saprophytes. Some pathogens carried by the soil like Fusarium and Vetiticillium do exist merely in vascular tissue and shows higher impact of parasitic specialization. One destructive disease namely wilt disease caused by Fusarium Oxysporum that leads to severe losses and damages in crops such as tomato, potato, castor, chick pea and cotton.

Usually to overcome these fungal diseases, some precautions take place like using chemicals resorting to some cultural traditions in agriculture, breeding for resistance and genetic engineering of crops can be helpful. Yet, not all the previous measurements are sufficient to completely control fungal pathogens. Huge quantities of chemicals such as methly bromide and methly isothiocyanate (MIT) chlopropicrin are being used to fight phytopathogenic fungs.

Subsequently, these chemicals had dramatic negative effects on health, soil salinity and affect passively the ecosystem. To avoid all the negative influences resulting by using chemicals, scientists thought of another method which is purely natural 
and that is using antagonistic microorganisms. These antagonistic microorganisms do exist in a roots area of plants, and we can find them more in suppressive soils. In fact, these microorganisms limits the numbers of fungal pathogens by two ways: direct and indirect; one way is affecting fungs directly by producing secondary metabolites like antibiotics that are poisonous to fungal pathogens. On the other hand, some antagonistic microorganisms can produce hydrolytic enzymes like chitinases or glucanases that dissolve and destroy the cell walls of fungal pathogens. The second way is the indirect way; where microorganisms control pathogens by using some nutrients of the soil and confine the fungs growth. The process where we control the spreading of the fungal pathogen diseases using other microbes without causing issues to the environment is called biological control (Siddiqui et al 2001 and Altindag et al 2006).

Wide range of microorganisms like fungi, bacteria, vesicular, arbuscular myccorhizal kinds have been tested and by evidence were proved to be biological control agents. Regarding the fungs proven to be agents of biological control, are Trichoderma, Gliocladium, Ampelomyces, Talaromyces, and Rhizopus. As for the bacterial types that show, greatly to be biological control agents are Pseudomonas and Bacillus. For example, Serratia Marcescens taken from soil were found to have great influence on fighting the diseases resulting by Sclerotium Rolfsii. Different species of Bacillus were involved in the biological control of fungal pathogen diseases. Several characteristics of these bacteria playing great role in identifying them to be naturally antagonistic including seeking nutrients in soil, releasing antibiotics and producing and discharging of hydrolytic enzymes.

It has been reported previously that those microorganisms, which are able to dissolve and destroy the cell wall of fungal pathogens, are the best to suppress their growth as they produce and release enzymes such as glucanases or chitinases.

Examinations were done to these antagonistic microorganisms that releasing chitinases and were well used to fight and confine the fungal diseases. These microorganisms produce and discharge chitinase enzymes which dissolve the chitin polymer existing In the cell wall of fungal mycelia and leads to their collapse.

Genes encoding for these chitinases have been cloned from various bacterial and fungal species. In earlier times, different species of Bacillus were proved to release chitinase enzymes. The Bacillus species releasing chitinase are $B$. licheni- formis, B. stearothermophilous, B. circulans, $B$. coagulans, B. megaterium and Bacillus cereus. Moreover, Bacillus thuringiensis that forms and discharge chitinase could immensely reinforce the insecticidal activity against Spodopetra littorals by 2.4 fold (Mostafa et al 2003).

In the present study, chitin degrading bacteria were isolated from soil samples collected from agricultural fields in Egypt. Optimization and characterization of chitinases, which were produced by the most potent species, Bacillus cereus were studied. These studies also included an examination of the antagonistic activity of the produced chitinases against some fungal pathogens and their effectiveness in increasing resistant of potato cultivars infected with various phytopathogenic fungi.

We are still studying the most potent chitinolytic bacterial isolate Bacillus cereus S3c for detection of the chitinase gene using $\mathrm{CHI}$ specific PCR primers and Cloning of the chitinase gene from the most potent isolate. Comparing the nucleotide sequence of chitinase gene isolated from the selected isolate with those of some other chitinase. Then, studying the effect of the selected bacterial isolate in the suppression of common fungal diseases in potato cultivars under greenhouse conditions. Scaling up the production of chitinase using fermentation technology and optimizing of fermentation protocol for the commercial production of chitinase.

\section{MATERIALS AND METHODS}

\section{SAMPLES COLLECTION}

Soil samples from agricultural fields (Buhayra, Sharqia and Alqilyubia of Egypt) were collected with clean shovels and transferred in to clean plastic bags. Three rhizosphere soil samples were randomly chosen and removed into plastic bags, transported to the laboratory within 12 hours and analyzed the same day.

\section{PREPARATION OF COLLOIDAL CHITIN}

Colloidal chitin was prepared as described by (Hsu and Lockwood, 1975) from crab shell chitin (Sigma). Forty grams of blenched chitin were dissolved in $400 \mathrm{ml}$ of concentrated $\mathrm{HCl}$ by stirring for 30-50 minutes. The chitin was precipitated as a colloidal suspension by mixing the solution with two liters of $4^{\circ} \mathrm{C}$ distilled water. After 48 hours, the supernatant was decanted and the precipitate was 
filtered to remove large pieces of undissolved chitin. The precipitate was centrifuged and washed with $0.2 \% \mathrm{~K}_{2} \mathrm{HPO}_{4}$, and the supernatant was removed in 5 to 6 repeated cycles. The resulting hydrolyzed chitin precipitate was used in the preparation of the chitin agar medium.

\section{Isolation of bacteria from rhizosphere soil}

From each soil samples one gram (dry weight) were suspended in $100 \mathrm{ml}$ sterile water and were shaken on a rotatory shaker for $90 \mathrm{~min}$ at $30^{\circ} \mathrm{C} .5$ $\mathrm{ml}$ of each suspension was incubated at $80^{\circ} \mathrm{C}$ for 10 minute to isolate spore formers bacteria (Travers et al 1987).

The isolation was initiated by making ten-fold dilutions of these suspensions in sterile distilled water. A $0.1 \mathrm{ml}$ aliquot of the serially diluted suspension was spread-plated on LB agar medium in triplicate. The spread-plate cultures were incubated for $24 \mathrm{~h}$. at $30{ }^{\circ} \mathrm{C}$. Ten to fifteen representative colonies, with different morphological appearances, were selected from the countable plates and re-streaked on a new plate but of the same media to obtain pure colonies. Dominant colonies were included in the isolation procedure. A total of 17 isolates originally obtained in this manner were maintained on LB agar slants.

\subsection{Isolation of chitin degrading bacteria}

For isolation of chitinase-producing microorganisms, a mineral medium containing colloidal chitin as sole carbon and energy source was used. Bacterial isolates were screened on agar plates containing colloidal chitin and incubated at $30^{\circ} \mathrm{C}$ for two days. Colonies surrounded by zones of clearance against the creamy background were regarded as chitinase-producing bacteria and were maintained at $4^{\circ} \mathrm{C}$ on agar plates.

\section{Identification of selected chitin degrading bacterial isolates}

\subsection{Morphological tests}

Morphological characteristics were analyzed according to the Bergey's Manual of Systematic Bacteriology (Sneath, 1986). The selected two different colonies, S1-C and S3-C were restreaked on LB agar plates for further purification. The colony morphological characters as color, form, configuration, margin, appearance, elevation and production of diffusible and non- diffusible pigments, was examined on LB medium. The Gram's stain was used to differentiate between Gram positive and Gram negative bacteria. Motility was determined by dotting each isolate onto motility plate, after incubation the isolate was scored as motile if the colony was observed to spread out from the incubation site.

\subsection{Physiological and biochemical tests}

Standard physiological and biochemical identification tests were carried out as described in Bergey's Manual of Systematic Bacteriology (Sneath, 1986). These include the growth in presence of different concentrations of $\mathrm{NaCl}(1-12 \%, w / v)$. The $\mathrm{pH}$ range of growth was determined on LB solid medium, initially adjusted to different $\mathrm{pH}$ 5-10 with $1 \mathrm{~N} \mathrm{HCL}$ or $1 \mathrm{~N} \mathrm{KOH}$. Temperature range was determined as above by incubation at 25, 30, 37, 40, 50,55 and $65^{\circ} \mathrm{C}$. The Voges-Proskauer test was used (including demonstration of the production of acetylmethylcarbinol by the isolates and checking the final $\mathrm{pH}$ of the broth). The production of acid and gas from glucose, mannitol and lactose was a differentiating test between bacilli. Fermentative capacity was shown by the yellow color change of indicator in the whole medium, while oxidative formation of acid only occurred on the upper part. A blue color indicated alkalinization. Gas production caused bubbles in the agar.

Hydrolysis of starch, casein, gelatin, chitin and urea, utilization of citrate, formation of indole, reduction of nitrate to nitrite, deamination of tryptophane and the catalase reaction were used to identify these isolated chitinolytic bacteria. Details of the media necessary for the performance of each of these testes for the differential and diagnostic characters are listed in the material section.

\subsection{S rRNA sequencing and analysis}

\section{Amplification of 16S rRNA gene}

Bacterial isolates were tested for species identity using the 16S rRNA sequencing method according to the methods of (Rochelle et al. 1995).16SrRNA analysis was carried out using specific universal primers for 16SrRNA, forward primer 27 F 5'-AGAGTTTGATCMTGGCTCAG-3' and reverse primer $1492 \mathrm{R}$ 5'TACCTTGTTACGACTT-3'. Isolated DNA from pure bacterial culture was used as template. PCR was performed with a $50 \mu \mathrm{l}$ reaction mixture containing $16 \mathrm{~S}$ gene primer, DNA template buffer, 
$\mathrm{MgCl}$, dNTPs and Taq polymerase. PCR program was carried out in Bio-RAD i-cycler which comprises of three steps; 1) Denaturation at $94^{\circ} \mathrm{C}$ for 40 seconds; 2) Annealing at $51^{\circ} \mathrm{C}$ for 50 seconds; 3 ) Extension at $72^{\circ} \mathrm{C}$ for 1.5 minute all running for 35 cycle, with initial denaturation $94 \stackrel{\circ}{\circ} \mathrm{C}$ for 4 minute and final extension $72 \stackrel{\circ}{\circ}$ for 7 minute. PCR Products were analyzed by electrophoresis in $1.5 \%$ agarose gel then one of them is gel-purified using (Promega Wizard SV Gel and PCR Clean Upsystem Kit cat. \# A9282). $4 \mu \mathrm{L}$ of the purified DNA PCR product was sequenced the gene; sequencing was done at Macrogen (South Korea). Obtained sequence was edited to exclude the PCR primer binding sites and manually corrected with Chromas 2.3 (Chromas version 2.3; www.technelysium.com.au. chromas.html).

Analysis of 16SrRNA gene sequence, Phylogenetic tree

16SrRNA gene sequence was compared with already submitted in database using the standard nucleotide-nucleotide BLAST algorithm (Altschul et al 1990). Further, most similar sequences were aligned by MEGA7 software, using the same software phylogenetic tree was constructed to analyze. The evolutionary history was inferred using the Neighbor-Joining method (Saitou N. and Nei M. et al 1987). The bootstrap consensus tree inferred from 1000 replicates is taken to represent the evolutionary history of the taxa analyzed (Felsenstein 1985). Branches corresponding to partitions reproduced in less than $50 \%$ bootstrap replicates are collapsed. The percentage of replicate trees in which the associated taxa clustered together in the bootstrap test (1000 replicates) is shown next to the branches (Felsenstein 1985). The evolutionary distances were computed using the Maximum Composite Likelihood method (Tamura et al 2004) and are in the units of the number of base substitutions per site. The analysis involved 19 nucleotide sequences. All positions containing gaps and missing data were eliminated. There were a total of 1545 positions in the final dataset. Evolutionary analyses [Phylogenetic tree] were conducted in MEGA6 (Kumar et al 2016).

5. Dual culture antifungal activity (assay of antifungal activity)

The antifungal activity was assayed in vitro by inhibiting the growth of phytopathogenic fungs on
PDA media (Altindag et al 2006). A mycelial plug (5 mm diameter) of F.oxysporum or R.solani Ware placed $2.5 \mathrm{~cm}$ away from the edging a petri dish and incubated at $30^{\circ} \mathrm{C}$ for one day. The bacterial inoculum of the two chitinolytic isolates S1-C, S3-C and ATCC 14580 was picked aseptically and streaked $4.5 \mathrm{~cm}$ away from the plug of F.oxysporum or R.solani on the same petri dish. The petri dish was incubated at $28 \stackrel{\circ}{ } \mathrm{C}$ for five days. The antagonism was expressed by measuring the magnitude of interactions that could appear. The effect of the bacteria on the fungi was categorized in a graduated scale as follows: $\mathbf{N}=$ No antagonism (mycelium formation not different from control); $\mathrm{W}=$ Weak antagonism (partial inhibition of mycelium formation mostly appearing as a less dense mycelium than that in control); $M$ =Moderate antagonism (almost complete inhibition of mycelium formation in the bacterial zone, but some hyphae escaped via growth through agar; $\mathrm{S}=$ Strong antagonism (complete inhibition and mycelium did not pass the bacterial zone) (De Boer et al 1999).

\section{RESULTS AND DISCUSSION}

1. Isolation, screening and identification of chitinolytic bacteria

\subsection{Isolation of chitin degrading bacteria}

Seventeen bacterial isolates have been successfully isolated and purified from a total of three rhizosphere soil samples, collected from rhizosphere of different commercial plants located in three different agriculture areas in Egypt; Buhayra, Sharqia and Alqilyubia of Egypt, during July 2018, the temperature of sampling day ranging from 35 $36{ }^{\circ} \mathrm{C}$. The bacteria were isolated using methods described by (Travers et al 1987) and others.

\subsection{Screening of chitin degrading bacteria us- ing plate assay}

The screening of chitin degrading bacteria was examined by spreading inoculum of each colony using puncturing on plates having minimal salt medium along with colloidal chitin as a sole source of carbon and energy. The microorganisms degrading chitin formed colonies of 1-2 mm. in diameter circled by clear zones due to chitinase activity.

Two isolates of a total number of 17 isolates exhibited different zones sizes of degradation of colloidal chitin on solid chitinase-inducing medium, 
some of these isolates showed highly chitinolytic activity others exhibited limited activity evidencing differences in their chitinolytic enzymes. In this assay the authentic chitinase producer Bacillus licheniformis Chester 1901AL (ATCC 14580) was used as a positive control. Two isolates designated S3-C and S1-C were selected for identification and for further studies (Figure 1) from the seventeen bacterial isolates that exhibited chitinase activity.

\section{Identification of selected chitin degrading bacterial isolates}

\subsection{Morphological and Biochemical Strains identification}

Identification including morphological observation, microscopic examination and physiological characteristics was used to identify the two local isolates to the species level. The results summarized in tables (Table 1, 2) showed that the two isolates S3-C and S1-C had smooth colonies. The results of microscopic examination revealed that isolates S3-C and S1-C are gram-positive (figure $2)$, motile, rod shaped and spore forming bacteria. No differences between S3-C and S1-C cells have been observed; both form motile rods of equal sizes $(1.2$ by $5.0 \mu \mathrm{m})$ and contain only one terminal endospore (Table1, 2).

Table 1. Morphological characters of colonies

\begin{tabular}{|c|c|c|c|c|c|}
\hline \multirow[b]{2}{*}{$\begin{array}{l}\text { Bacterial } \\
\text { isolates }\end{array}$} & \multicolumn{5}{|c|}{ Colony morphology } \\
\hline & Shape & Elevation & Edge & Color & $\begin{array}{l}\text { Sur- } \\
\text { face }\end{array}$ \\
\hline$S 1-C$ & Irregular & Flat & Branched & White & Smooth \\
\hline S3-C & Irregular & Flat & Branched & White & Smooth \\
\hline
\end{tabular}

Isolate S3-C and S1-C have the same colony morphology.

Table 2. Microscopic examination of cells

\begin{tabular}{|c|c|c|c|c|c|}
\hline \multirow{2}{*}{$\begin{array}{c}\text { Bacterial } \\
\text { isolates }\end{array}$} & \multicolumn{5}{|c|}{ Cell morphology and character } \\
\cline { 2 - 6 } & Form & $\begin{array}{c}\text { Gram } \\
\text { reaction }\end{array}$ & Endospore & $\begin{array}{c}\text { Parasporal } \\
\text { bodies }\end{array}$ & Motility \\
\hline S1-C & Rod & + & + & - & + \\
S3-C & Rod & + & + & - & + \\
\hline
\end{tabular}

Isolate S3-C and S1-C have the same cell morphology and character Form: Rod, Gram reaction: (+), Endospore :(+) and Motility: $(+)$.
Table 3. A Physiological and biochemical characteristic of chitinolytic bacterial isolates $S 1-C$ and S3-C.

\begin{tabular}{|c|c|c|}
\hline \multirow{2}{*}{ Characteristics } & \multicolumn{2}{|c|}{ Bacterial isolates } \\
\hline & S1-C & S3-C \\
\hline Catalase test & + & + \\
\hline Anaerobic growth & + & + \\
\hline Voges-Proskauer test & + & + \\
\hline $\begin{array}{l}\text { Methyl red test } \\
\text { PH in V-P Broth }\end{array}$ & - & - \\
\hline$<<6$ & + & + \\
\hline$\bullet>7$ & - & - \\
\hline Hydrolysis of & & \\
\hline - Casein & + & + \\
\hline - Gelatin & 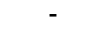 & - \\
\hline - Starch & + & + \\
\hline - Chitin & + & + \\
\hline - Urea & - & - \\
\hline Utilization of citrate & - & - \\
\hline Lipase & + & + \\
\hline B-galactosidase & + & + \\
\hline Arginine dihydrolase & + & + \\
\hline Lysine decarboxylase & - & - \\
\hline Ornithine decarboxylase & - & - \\
\hline Tryptophane deaminase & - & + \\
\hline Nitrate to nitrite & + & + \\
\hline Gas from nitrate & - & - \\
\hline Formation of indole & - & - \\
\hline O/F Media & & \\
\hline - Glucose & $+\mathrm{F}$ & $+\mathrm{F}$ \\
\hline - Sucrose & $+\mathrm{F}$ & $+\mathrm{F}$ \\
\hline - Mannitol & $+\mathrm{F}$ & $+\mathrm{F}$ \\
\hline - Lactose & $+\mathrm{F}$ & $+\mathrm{F}$ \\
\hline Acid from & & \\
\hline - D-glucose & + & + \\
\hline - D-mannitol & - & - \\
\hline - Inositol & - & - \\
\hline - D-sorbitol & - & - \\
\hline - L-rhamnose & - & - \\
\hline - D-sucrose & + & - \\
\hline $\begin{array}{l}\text { - D-melibiose } \\
\text { - L-arabinose }\end{array}$ & & $\begin{array}{l}- \\
-\end{array}$ \\
\hline $\mathrm{H}_{2} \mathrm{~S}$ production & - & - \\
\hline Blood hemolysis & + & + \\
\hline Growth at & & \\
\hline - $5{ }^{\circ} \mathrm{C}$ & - & - \\
\hline - $30^{\circ} \mathrm{C}$ & + & + \\
\hline - $40^{\circ} \mathrm{C}$ & + & + \\
\hline - $50^{\circ} \mathrm{C}$ & + & + \\
\hline - $55^{\circ} \mathrm{C}$ & - & - \\
\hline - $65^{\circ} \mathrm{C}$ & - & - \\
\hline
\end{tabular}

Table 3. The tow new strains were positive in the following examinations: Catalase, anaerobic growth, hydrolysis of casein, lipase, growth at $30^{\circ} \mathrm{C}$ and at $40^{\circ} \mathrm{C}$.All strains were negative in the following examinations : Formation of indole, Ornithine decarboxylase, Gas from nitrate, growth at $5^{\circ} \mathrm{C}$, growth at $65^{\circ} \mathrm{C}$ and $\mathrm{H}_{2} \mathrm{~S}$ production. (ND= not determined). 

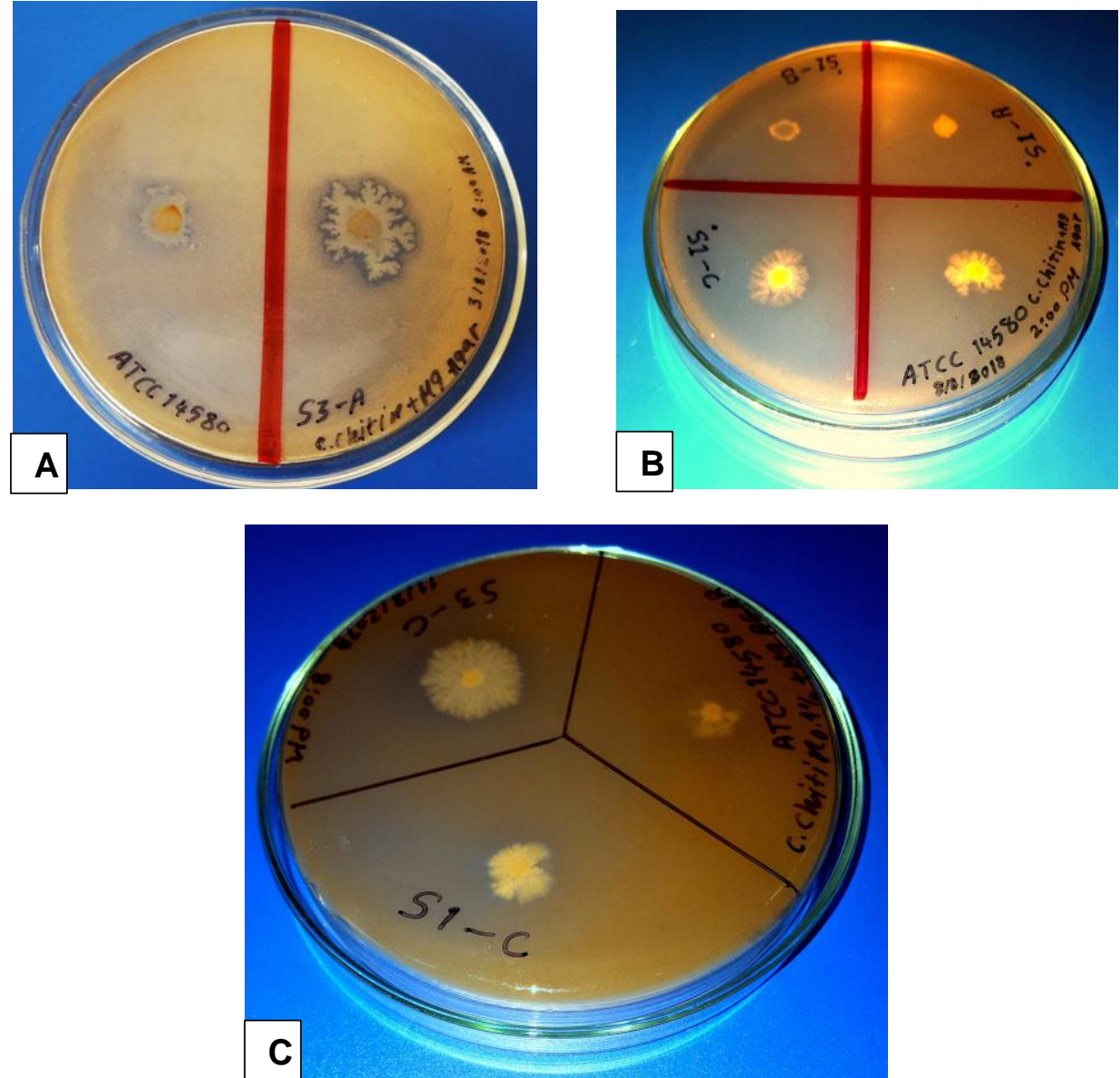

Fig. 1. Plate assay showing chitinase activities of local isolates on M9 media supplemented with $1 \%$ $(\mathrm{w} / \mathrm{v})$ colloidal chitin. The formation of clear zones is apparent with isolates S3-C (image A,C) and S1C (Image B, C) compared to other isolates showing limited clear zones or no clear zones with ATCC14580 as Control .
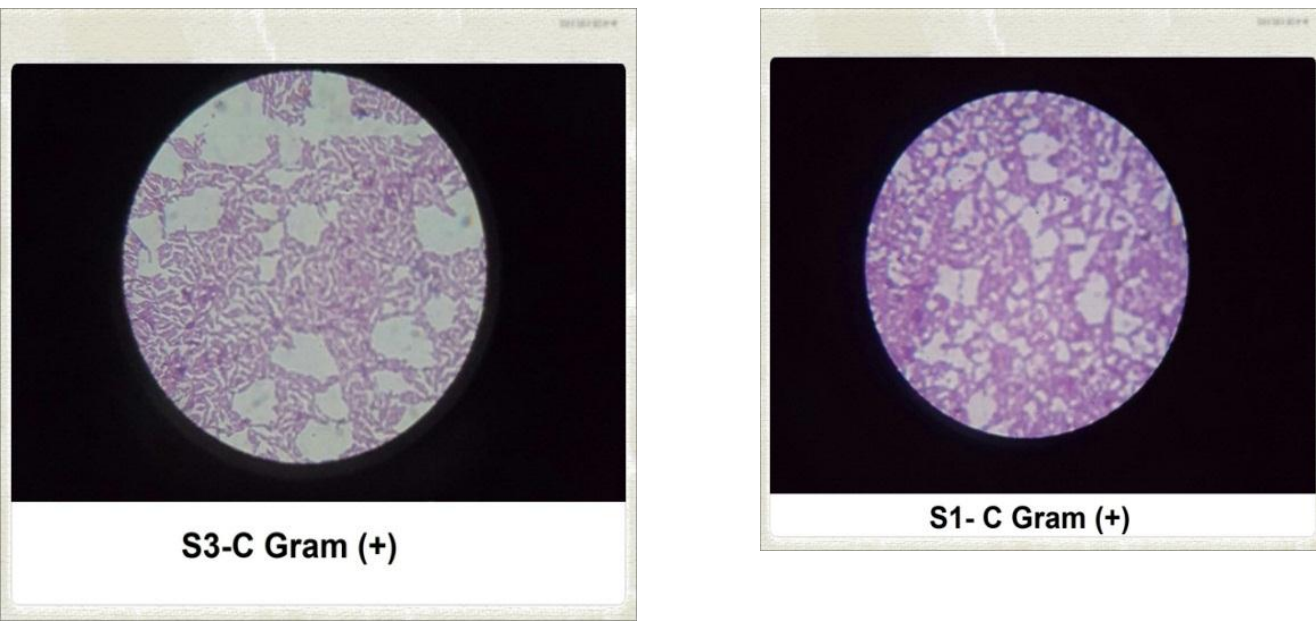

S1- C Gram (+)

Fig. 2.Isolate S3-C and S1-C Bacteria and have the same morphology Rod shape and Gram (+). 
Based on morphological, physiological and biochemical results summarized in tables $1,2,3$, the isolates S1-C and S3-C were identified to the species level. The outcomes of these examinations were similar to those of Bergey's Manual of Systematic Bacteriology (Sneath, 1986).

Moreover, the isolates S1-C and S3-C proved to have the same outcomes of biochemical examinations and identified as Bacillus Cereus. However, definite evidence for the affiliation of the isolates with the species $B$. cereus was obtained from sequencing the 16S rRNA gene.

\subsection{S rRNA sequencing and analysis}

To assure the identification of isolates S3-C and $S 1-C$; an analysis of gene sequence of $16 S$ rRNA has been executed. The sequence alignment using BLAST (Basic Local Alignment Search Tool) software for the comparison of up to $980 \mathrm{bp}$ Figure 4) of $S 3-C$ and $S 1-C$ (Figure 5) gave high homology (99\%) with Bacillus cereus strain AHSM124 16S rRNA gene partial sequence accession: MK074711.1, Bacillus cereus gene for 16S rRNA partial sequence, strain: DLTA4.32 accession: LC208134.1, Bacillus cereus gene for 16S rRNA partial sequence, strain: SBABrB5 accession: LC189361.1, Bacillus cereus gene for 16S rRNA partial sequence, strain: SBFWS5 accession: LC189359.1, Bacillus cereus strain BA8 16S rRNA gene, partial sequence accession: KU510055.1, Bacillus sp. GG3 (2015) gene for 16S rRNA partial sequence accession: LC055679.1, Bacillus cereus strain LP13_RH08 16S rRNA gene, partial sequence accession: KT427911.1, Bacillus sp. (in: Bacteria) strain CZW12 16S rRNA gene, partial sequence accession: MG866081.1, Bacillus cereus strain CZW-5 16S rRNA gene, partial sequence accession: MG866079.1 and Bacillus sp. (in: Bacteria) strain 18JY8-13 16S rRNA gene partial sequence accession: MK101106.1.

\section{Nucleotide sequence accession numbers}

Sequences obtained for Bacillus cereus S3-C and Bacillus cereus S1-C in this study were deposited in GenBank under the following accession numbers: 16S rRNA gene partial sequence; MK185696 and MK185697.

\section{Phylogenetic analysis}

Phylogenetic tree (Figure 6) was drawn with both new isolate and its closest relative which determinate on the basis of highest score obtained in the MEGA6 result, tree constructed for the determination of evolutionary relatedness. New isolates designated as S3-C and S1-C were found to be closely related to accessions MK074711.1 and accessions LC208134.1 respictraely.

Definite evidence for the affiliation of the isolates S3-C and S1-C with the species Cereus was obtained from PCR (figure 3 ) and sequencing the 16S rRNA gene:

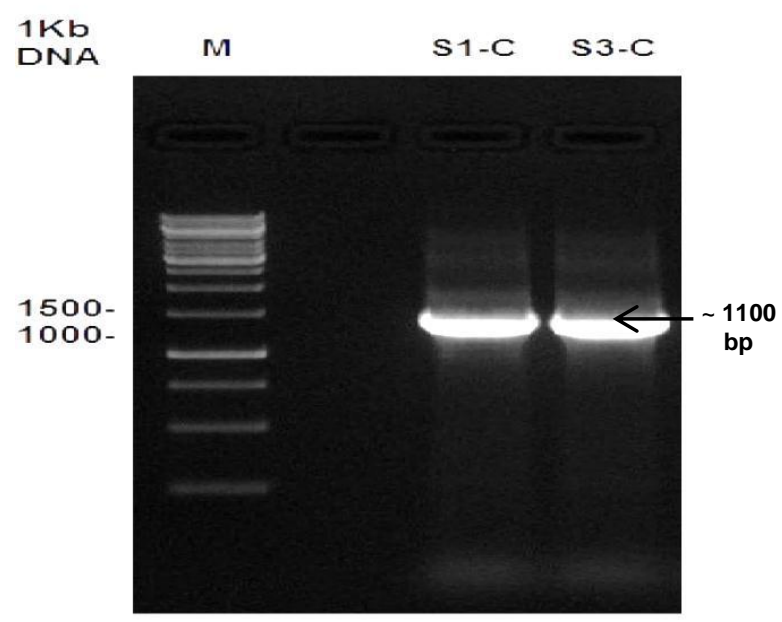

Fig. 3: Amplification of $16 \mathrm{SrRNA}$ gene from of isolates S3-C and S1-C. M: 1kb DNA ladder GeneRuler $^{\mathrm{TM}} 1 \mathrm{~kb}$ Fermentas, catg. \# SM0311, lane (S1-C): amplification of 16SrRNA gene from Isolate S1-C and lane (S3-C): 16SrRNA gene amplification form Most Potent Isolate S3-C.

\section{Dual culture antifungal activity of the two selected chitinolytic isolates}

Studies have been made via hyphal extention inhibition examinations to prove the effectiveness of chitin degrading bacteria isolates against fungal pathogens such as Rhizoctonia solani and Fusarium oxysporum. that infecting plants and cause damping off disease. The results demonstrated that isolate S3-C was more effective than isolate $\mathrm{S} 1-\mathrm{C}$ in inhibition of fungal mycelium comparing with control, therefore it is considered as the most potent effective isolates against all the examined phytopathogens. 
$>$ New Isolate S3-C 16s rRNA 27F 980bp

TTGCTCTTATGAAGTTAGCGGCGGACGGGTGAGTAACACGTGGGTAACCTGCCCATAAGAGTGGG ATAACTCCGGGAAACCGGGGCTAATACCGGATAACATTTTGAACCGCATGGTTCGAAATTGAAAGG CGGCTTCGGCTGTCACTTATGGATGGACCCGCGTCGCATTAGCTAGTTGGTGAGGTAACGGCTCACC AAGGCAACGATGCGTAGCCGACCTGAGAGGGTGATCGGCCACACTGGGACTGAGACACGGCCCAG ACTCCTACGGGAGGCAGCAGTAGGGAATCTTCCGCAATGGACGAAAGTCTGACGGAGCAACGCCG CGTGAGTGATGAAGGCTTTCGGGTCGTAAAACTCTGTTGTTAGGGAAGAACAAGTGCTAGTTGAAT AAGCTGGCACCTTGACGGTACCTAACCAGAAAGCCACGGCTAACTACGTGCCAGCAGCCGCGGTAA TACGTAGGTGGCAAGCGTTATCCGGAATTATTGGGCGTAAAGCGCGCGCAGGTGGTTTCTTAAGTC TGATGTGAAAGCCCACGGCTCAACCGTGGAGGGTCATTGGAAACTGGGAGACTTGAGTGCAGAAG AGGAAAGTGGAATTCCATGTGTAGCGGTGAAATGCGTAGAGATATGGAGGAACACCAGTGGCGA AGGCGACTTTCTGGTCTGTAACTGACACTGAGGCGCGAAAGCGTGGGGAGCAAACAGGATTAGAT ACCCTGGTAGTCCACGCCGTAAACGATGAGTGCTAAGTGTTAGAGGGTTTCCGCCCTTTAGTGCTGA AGTTAACGCATTAAGCACTCCGCCTGGGGAGTACGGCCGCAAGGCTGAAACTCAAAGGAATTGAC GGGGGCCCGCACAAGCGGTGGAGCATGTGGTTTAATTCGAAGCAACGCGAAGAACCTTACCAGGT

Fig. 4. New Isolate Bacillus cereus S3-C 16 rRNA Partial Sequence.

>New Isolate S1-C 16s rRNA 27F 1075bp

CCAGGGCGGCTGCCTATACATGCAGTTCGAGCGAATGGATTAAGAGCTTGCTTCTTATGAAGTTAG CGGCGGACGGGTGAGTAACACGTGGGTAACCTGCCCATAAGACTGGGATAACTCCGGGAAACCGG GGCTAATACCGGATAACATTTTGAACCGCATGGTTCGAAATTGAAAGGCGGCTTCGGCTGTCACTT ATGGATGGACCCGCGTCGCATTAGCTAGTTGGTGAGGTAACGGCTCACCAAGGCAACGAGCGTAG CCGACCTGAGAGGGTGATCGGCCACACTGGGACTGAGACACGGCCCAGACTCCTACGGGAGGCAG CAGTAGGGAATCTTCCGCAATGGACGAAAGTCTGACGGAGCAACGCCGCGTGAGTGATGAAGGCT TTCGGGTCGTAAAACTCTGTTGTTAGGGAAGAACAAGTGCTAGTTGAATAAGCTGGCACCTTGACG GTACCTAACCAGAAAGCCACGGCTAACTACGTGCCAGCAGCCGCGGTAATACGTAGGTGGCAAGC GTTATCCGGAATTATTGGGCGTAAAGCGCGCGCAGGTGGTTTCTTAAGTCTGATGTGAAAGCCCAC GGCTCAACCGTGGAGGGTCATTGGAAACTGGGAGACTTGAGTGCAGAAGAGGAAAGTGGAATTC CATGTGTAGCGGTGAAATGCGTAGAGATATGGAGGAACACCAGTGGCGAAGGCGACTTTCTGGTC TGTAACTGACACTGAGGCGCGAAAGCGTGGGGAGCAAACAGGATTAGATACCCTGGTAGTCCACG CCGTAAACGATGAGTGCTAAGTGTTAGAGGGTTTCCGCCCTTTAGTGCTGAAGTTAACGCATTAAG CACTCCGCCGGGGGAGTACGGCCGCAAGGCTGAAACTCAAAGGAATTGACGGGGGCCCGCACAA GCGGTGGAGCATGTGGTTTAATTCGAAGCAACGCGAAGAACCTTACCAGGTCTTGACATCCTCTGA CAACCCTAGAGATAGGGCTTCTCCTTCGGGAGCAAAATGACAGGTGGTGCAGGGTTGTCCTCACCT CCTGTCCTGAAAATTTTGGGTTAATTCCC

Fig. 5. New Isolate Bacillus cereus S1-C 16 rRNA Partial Sequence. 


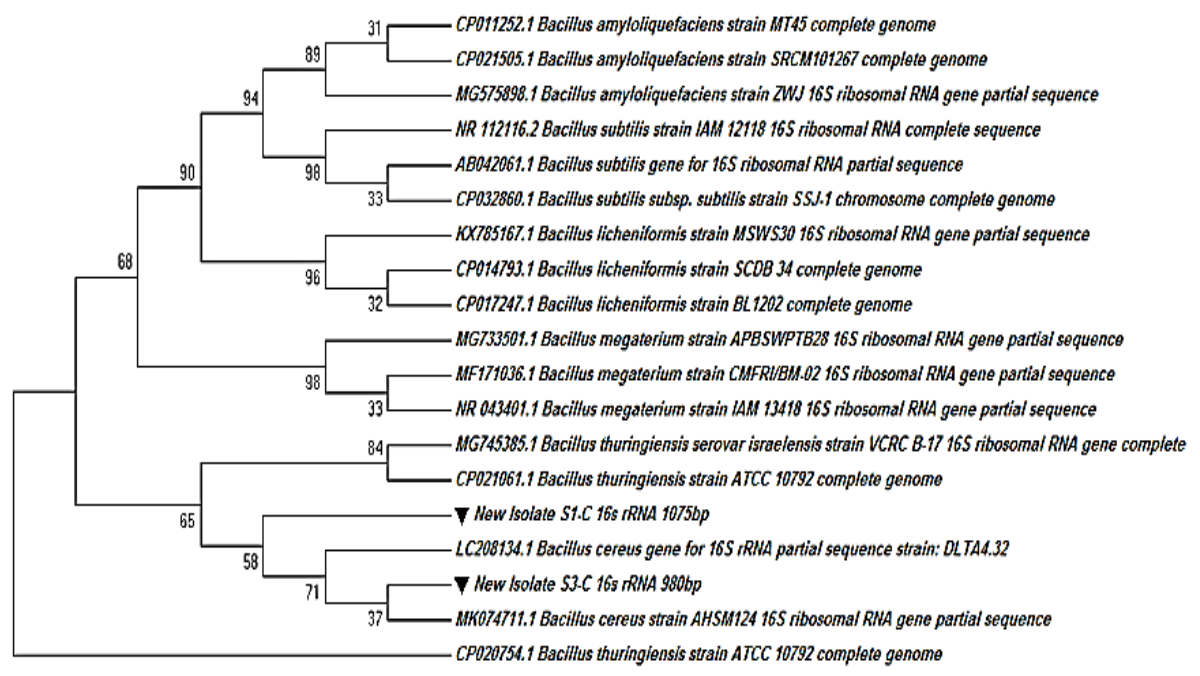

Fig. 6.Evolutionary relationships of taxa (phylogenetic Tree) of Two New Isolates Bacillus cereus S3-C and S1-C.

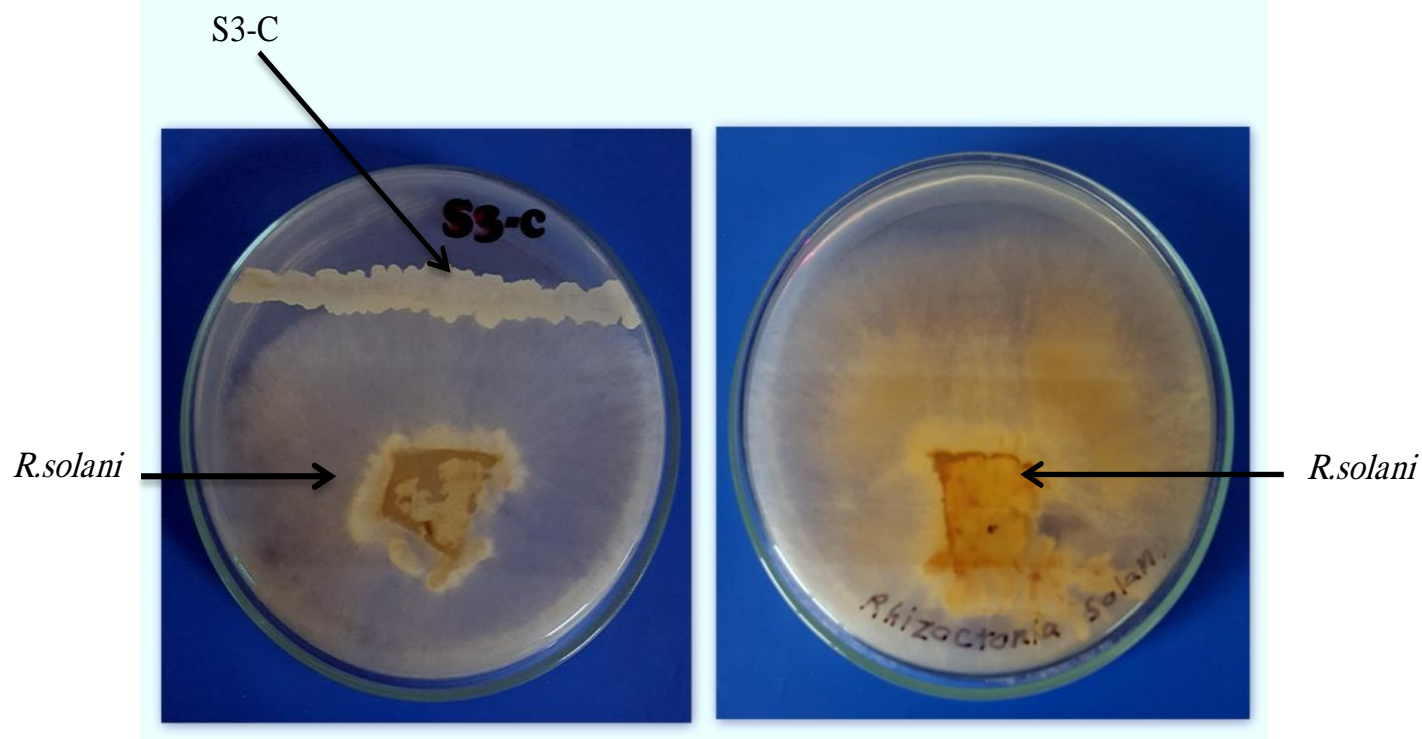

Fig. 7. In vitro antifungal activity of Bacillus Cereus S3-C against fungal pathogen R.solani compared with Control without bacteria on PDA medium at $35^{\circ} \mathrm{C}$. 

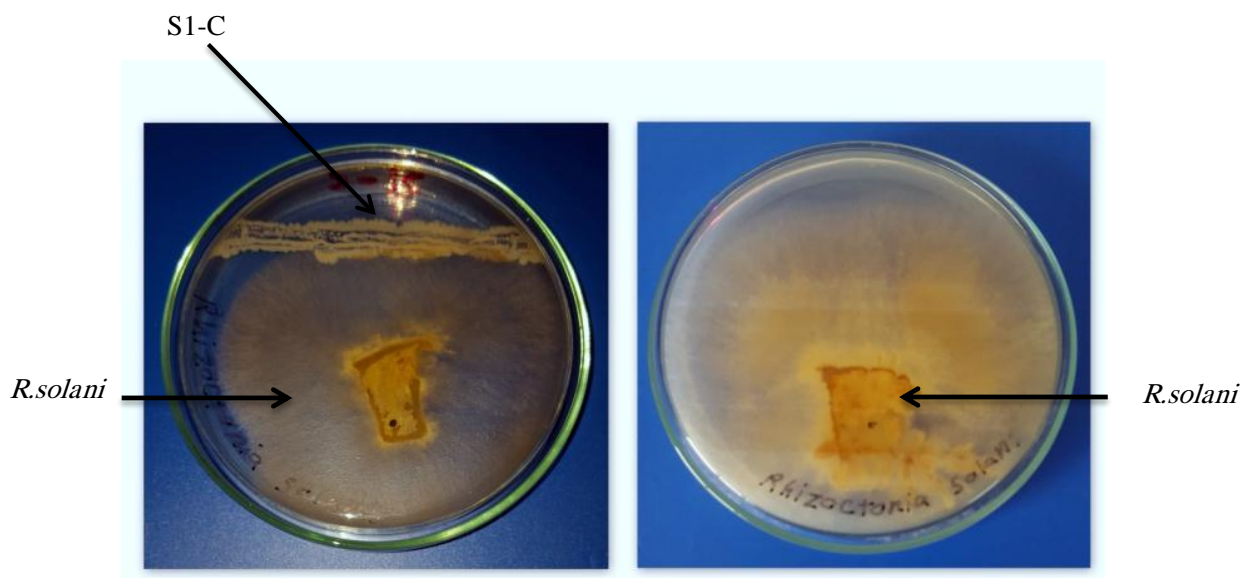

Fig. 8. In vitro antifungal activity of Bacillus Cereus S3-C against fungal pathogen $\boldsymbol{R}$. solani compared with Control without Bacteria on PDA medium at $35^{\circ} \mathrm{C}$.
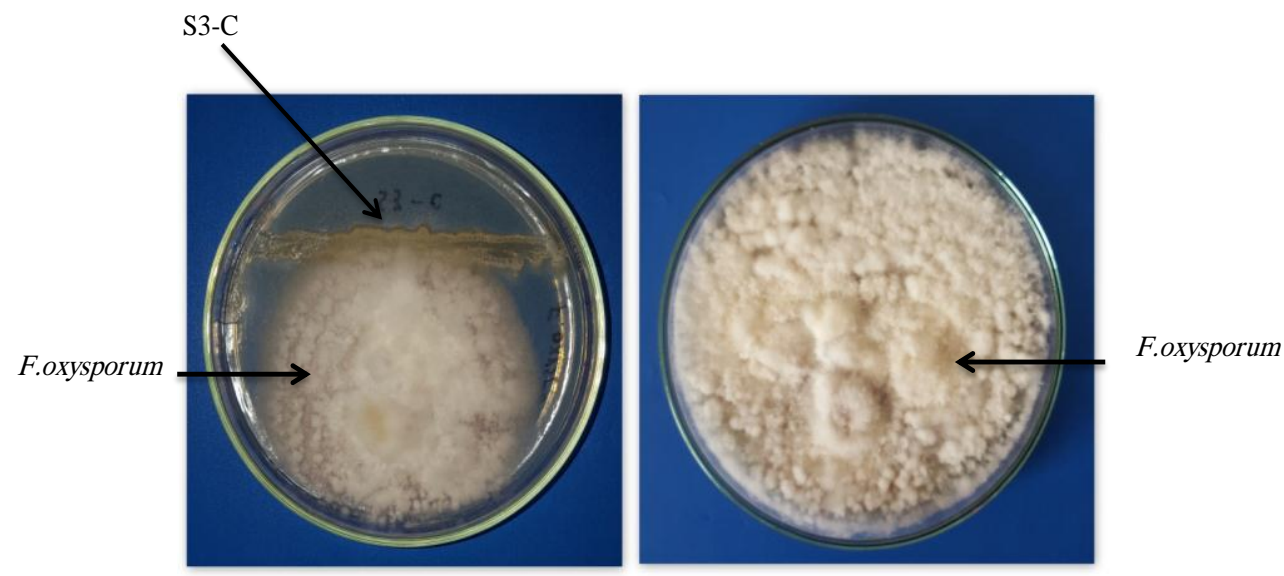

Fig. 9. In vitro antifungal activity of Bacillus Cereus S3-C agents fungal pathogen $\boldsymbol{F}$. oxysporum compared with Control without bacteria on PDA medium at $35^{\circ} \mathrm{C}$.
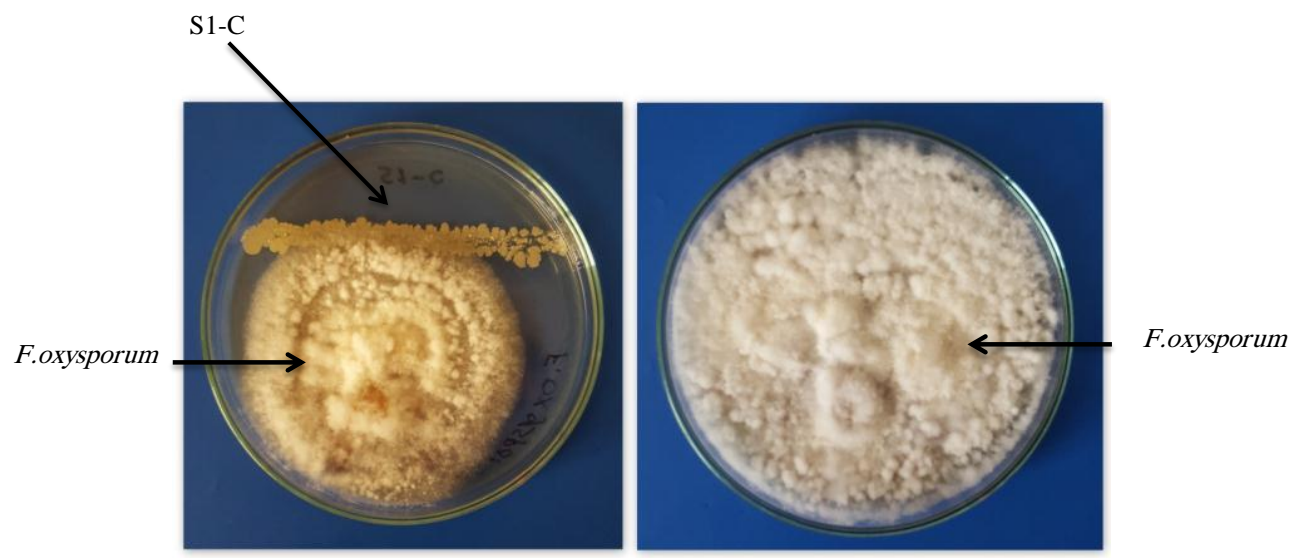

Fig. 10. In vitro antifungal activity of Bacillus Cereus S1-C agenst fungal pathogen F.oxysporum compared with Control without Bacteria on PDA medium at $35^{\circ} \mathrm{C}$. 
In contrast, fungal growth of Rhizoctonia solani was inhibited by isolates S3-C and S1-C (Table 4). The effective isolates taken into consideration are merely those capable of producing clear zones of inhibition or able to lyse the cell walls of fungal mycelium. Plates not treated with the bacterial isolates were used as a negative control. These plates were covered completely by the phytopathogens and showing no inhibition. Antifungal activity of Bacillus cereus S3-C and S1-C against Rhizoctonia solani and Fusarium oxysporum have been compared (figure 7, 8, 9 and 10). The former showed wide clear inhibition zone while the latter resulted in no inhibition zones.

Table 4. Symbols for reaction types: $\mathbf{M}$ stands for Moderate antagonism, W stands for weak antagonism and $\mathbf{S}$ stands for strong antagonism.

\begin{tabular}{|c|c|c|}
\hline \multirow{2}{*}{$\begin{array}{c}\text { Bacterial } \\
\text { isolates }\end{array}$} & \multicolumn{2}{|l}{$\begin{array}{l}\text { The following fungal pathogens are } \\
\text { fought by the inhibition activities of the } \\
\text { isolates: }\end{array}$} \\
\cline { 2 - 3 } & R. solani & F. oxysporum \\
\hline S3-C & S & S \\
S1-C & M & M \\
\hline
\end{tabular}

\section{REFERENCES}

Altschul, S.F., Gish W., Miller W., Myers E.W. and Lipman D.J., 1990. Basic local alignment search tool. J. Mol. Biol., 215, 403-410.

Altindag, M., Sahin, M., Esitken, A., Ercisli S., Guleryuz, M., Donmez, F.M. and Sahin, F. 2006. Biological control of brown rot (Moniliana laxa Ehr.) on apricot (Prunus armeniaca L. cv. Hacıhaliloğlu) by Bacillus, Burkholdria, and Pseudomonas application under in vitro and in vivo conditions. J. Biol. Cont. 38 (3), 369-372.

Bhattacharya D1, Nagpure A and Gupta RK 2007. School of Biotechnology, Guru Gobind Singh Indraprastha University, Delhi, India. Crit Rev. Biotechnol., Jan-Mar., 27(1), 8-21

De Boer, W., Klein Gunnewiek, P.J. A., Lafeber, P., Janse, J.D., Spit, B.E. and Woldendorp, J.W., 1999. Antifungal properties of chitinolytic dune soil bacteria. Soil Biol. Biochem. 30, 193-203.
Felsenstein J., 1985. Confidence limits on phylogenies: An approach using the bootstrap. Evolution 39, 783-791.

Hsu, S.C. and Lockwood, J.L., 1975. Powdered chitin agar as a selective medium for enumeration of Actinomycetes in water and soil. Appl. Microbiol. 29, 422-426.

Kumar S., Stecher G. and Tamura K., 2016. MEGA6: Molecular Evolutionary Genetics Analysis version 7.0 for bigger datasets. Molecular Biology and Evolution 33, 1870-1874.

Mostafa, S.A., Anan, M.R., Ibrahim, M.A., Osman, G.A. and Gad El-Karim G.A., 2003. Chitinase-producing Bacillus thuringiensis isolate BT-22 with enhanced toxicity towards cotton leaf worm (Spodoptera littoralis). Egypt. J. Genet. Cytol. 32, 167-173.

Rochelle, P.A., Will, J.A., Fry, J.C., Jenkins, G.J., Parkes, R.J., Turley, C.M., and Weightman, A.J., 1995. Extraction and amplification of 16S rRNA genes from deep marine sediments and seawater to assess bacterial community diversity. pp. 219-239. In: Trevors, J.T. and van Elsas, J.D. (eds.), Nucleic Acids in the Environment.

Saitou, N. and Nei M., 1987. The neighbor-joining method: A new method for reconstructing phylogenetic trees. Molecular Biology and Evolution 4, 406-425.

Siddiqui, I.A., Ehetshamul-Haque, S. and Shaukat, S.S., 2001. Use of rhizobacteria in the control of root rot-root knot disease complex of mungbean. J. Phytopatho 149, 337346.

Sneath, P.H.A. 1986. Endospore forming grampositive rods and cocci. In: "Bergey's Manual of Systematic Bacteriology, Vol. 2." (Sneath, P.H.A., Mair, N.S., Sharpe, M.E. and Holt, J.G. eds.). pp. 1104-1137, 1288-1301.

Tamura K., Nei M., and Kumar S. 2004. Prospects for inferring very large phylogenies by using the neighbor-joining method. Proceedings of the National Academy of Sciences (USA), 101, 11030-11035.

Travers, R.S., Martin, P.A.W. and Reichelderfer, C.F., 1987. Selective process for efficient isolation of soil Bacillus spp. Appl. Environ. Microbiol. 53, 1263-1266. 

المؤتمر الرابع عثر لبحوث التنمية الزراعية،

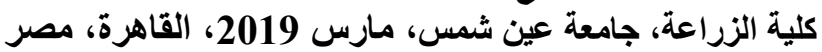

مجلا(27)، عدد (1)، عدد خاص مارس، مارس، 2019 (160-749، 2019

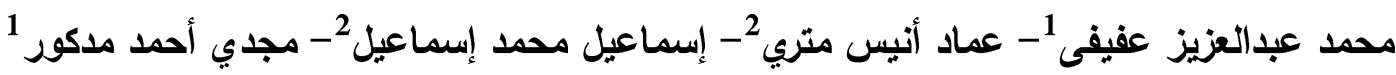

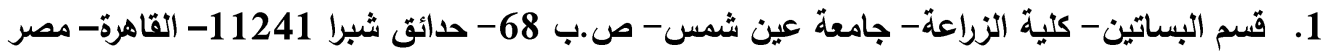

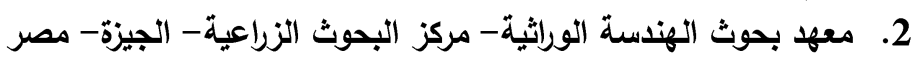

"Corresponding author: madkour.magdy@gmail.com

Received 26 November, 2018,

Accepted 18 December, 2018

كما تم إختبار ن نشاط الكيتينيز للعزلتين B.cereus S1C و B.cereus S3C

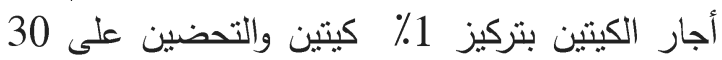
درجة مئوية لمدة خمسة أيام.

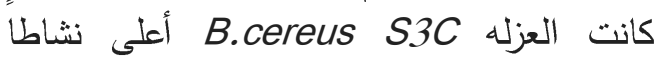
لتحليل جدار الخلية للعديد من الفطريـات الممرضة

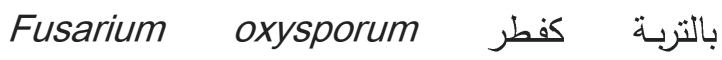
PDA Rhizoctonia solanig وذللك على بيئة ودرجة حرارة تحضين 30 درجة مئوية. فكانت إضافة فئة

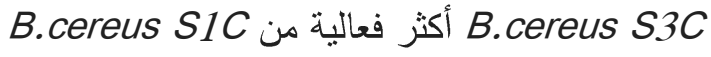

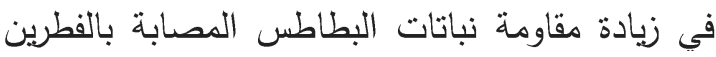
المختبرين المحمولين بالتربة.

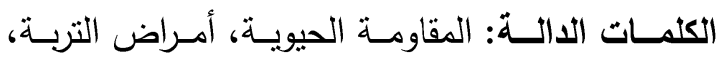

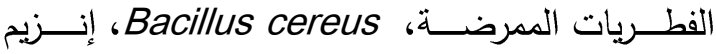
الكيتينيز ، تقدير نشاط الميكروب لإفراز الإنزيم، تقدير نشاط الإنزيم في المكافحة الحيوية.

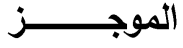

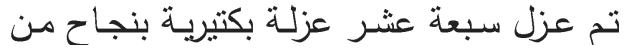

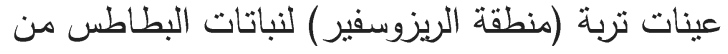

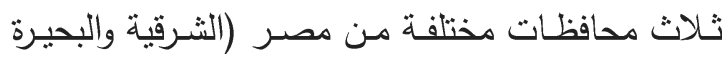
والقليوبيـة) وتم إختبـارهم لنشـاط إنتاج إنزيم الكيتينيز

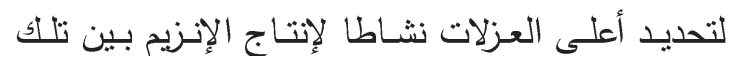

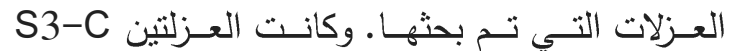
و وأعلى العزلات نشاطا فى أنتاج أنزيم الكيتنيز العزيز

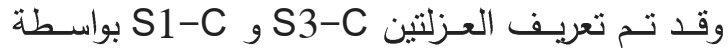
16s rRNA الاختبارات البيوكيميائية والفسيولوجية ولتين والت

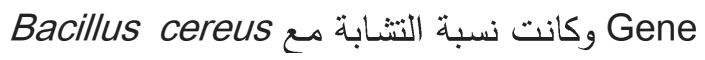
حوالى 99\% وقد تم تعريفهم وتسجيلهر بال GeneBank International NCBI Bacillus cereus S3-C accession MK185696, Bacillus cereus $S 1-C$ accession MK185697. 